Trinity University

Digital Commons @ Trinity

Modern Languages and Literatures Faculty

Research

Modern Languages and Literatures Department

2017

\title{
The Dark Pastoral: A Trope for the Anthropocene
}

Heather I. Sullivan

Trinity University, hsulliva@trinity.edu

Follow this and additional works at: https://digitalcommons.trinity.edu/mll_faculty

Part of the Modern Languages Commons

\section{Repository Citation}

Sullivan, H. I. (2017). The dark pastoral: A trope for the Anthropocene. In C. Schaumann \& H. I. Sullivan (Eds.), German ecocriticism in the anthropocene (pp. 25-44). Palgrave Macmillan.

This Contribution to Book is brought to you for free and open access by the Modern Languages and Literatures Department at Digital Commons @ Trinity. It has been accepted for inclusion in Modern Languages and Literatures Faculty Research by an authorized administrator of Digital Commons @ Trinity. For more information, please contact jcostanz@trinity.edu. 
Literatures, Cultures, and the Environment focuses on new research in the Environmental Humanities, particularly work with a rhetorical or literary dimension. Books in this series explore how ideas of nature and environmental concerns are expressed in different cultural contexts and at different historical moments. They investigate how cultural assumptions and practices, as well as social structures and institutions, shape conceptions of nature, the natural, species boundaries, uses of plants, animals and natural resources, the human body in its environmental dimensions, environmental health and illness, and relations between nature and technology. In turn, the series makes visible how concepts of nature and forms of environmen list thought and representation arise from the confluence of a community's ecological and social conditions with its cultural assumptions, perceptions, and institutions.

More information about this series at

http://www.springer.com/series/14818
Caroline Schaumans - Heather I. Sullivan Editors

\section{German Ecocriticism in the Anthropocene}

\author{
palgrave \\ macmillan
}

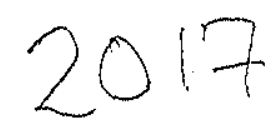




\title{
The Dark Pastoral: A Trope for the Anthropocene
}

\author{
Heather I. Sullivan
}

Denoting our current age as the Anthropocene, or the era of planet-wide human impact, scales up human agency beyond the usual biological capacity of all living things to alter their surroundings to a geological force. Human activities have altered vast areas of the Earth's terrestrial surfaces, spread indusurial particulates across the globe, and impacted the planetary climate with increased release of carbon dioxide that then increases oceanic acidity bleaching entire coral reefs. The biosphere's land, air, and water have all changed with the increased release and use of energy. Once again, a species of living things has become a large-scale force on planet Earth, as did cyanobacteria during the Archaean and Proterozoic eras and as plants did when they conquered terrestrial spaces, covering much of our world in green. This time, however, a thinking species with a new level of technological intelligence is envisioning and enacting these changes. Hence environmen studies must attend to the human cultural imagination in order to understand what we have been thinking or not thinking, why, and what we might think (and attempt) in the future.

This study of the "dark pastoral" offers a specifically literary frame for environmental studies and the environmental humanities, since stories and narrative forms are one of human beings' oldest anid most powerfilly

H.I. Sullivan (函)

Trinity University, San Antonio, TX, USA

(C) The Author(s) 2017

C. Schaumann, H.I. Sullivan (eds.), German Ecocriticism in

the Anthropocene, Literatures, Cultures, and the Environment,

DOI 10.1057/978-1-137-54222-9_3 
moving strategies for describing our identities, relationships, the connection to our surroundings, and our origins. There are two sides to this particular trope that make it especially apt for the Anthropocene among the wide array of human-land visions: first is the long history of traditional pastoral texts providing ample historical examples of a nostalgia for idealized rural landscapes occupied by peaceful folk seemingly in harmony with natural cycles but always already lost. ${ }^{2}$ Such a view is actually as old as antiquity. New, however, is the second side of the dark pastoral, that is, the darkness of our rapidly growing knowledge about industrial cultures' tainted tactics when accessing and using "natural resources" and the standard obliviousness to the resultant waste. Unlike traditional pastorals, the darkened trope is not a designated literary genre but rather a tool for describing our imagination, and enactment, of the human-environment relationship specifically in the fossil-fueled Anthropocene. As Serenella Iovino, Serpil Oppermann, and other scholars of material ecocriticism have made clear in ecological terms in conjunction with postcolonialism and postmodernism, our attitudes, texts, and our practices transform in varying ways our physical and cultural realities. The dark pastoral, however, also functions as a trope of exposure, in that it brings to our attention the seemingly hidden and ignored costs of global industrial capitalism such as the industrial waste that is intimately connected to modern agriculture but not shown in lovely photos of green farms.

The dark pastoral thus reflects several new ideas; for one, the realization that we might legitimately call this geological era the Anthropocene due not to human exceptionalism but rather to our (often unintended) environmental impact and, for another, the dawning recognition of industry's, colonialism's, and “ecological imperialism's" re-shaping of Earth's humanly inhabitable places through land-altering agriculture and the accelerated development of fossil fiels and fossil-ficl-formed fertilizers (Latham; Nixon; DeLoughrey and Handley; Huggan and Tiffin; Roos and Hunt and Shiva). It grapples with the problem of thinking on a planetary scale while recognizing the need for the local, as Ursula $K$ Heise describes in her 2008 Sense of Place and Sense of Planet. And the dark pastoral also brings into the light, so to speak, the very economic and urban centers that are elided in traditional literary pastoral renderings of rural landscapes. Yet the dark pastoral retains the focus on human beings on the land (cities and industrial sites are on land, too, for the most part), engaging with seasonal cycles, vegetation, water, the non-human, and the other lives that fuel us whether plant or animal. This chapter uses the dark pastoral trope as a lens to reconsider an array of depictions of the human-environment relationships in texts from Goethe to Ilija Trojanow, each one expressing a different aspect of the darkly pastoral characteristics of the Anthropocene and each with a different understanding of human and non-human agency. The various scenarios of the human-land relationship in terms of our agency provide an Anthropocenic mosaic in which a deeply felt pastoral love of specifically humanized landscapes combines with devastating disasters of natural-cultural origins and no clear solutions. The dark pastoral functions within such unbridgeable divides and is thus a trope of paradox and contrast, of irony and exposure. Yet it continues to tell stories, since stories easily contain irony and are part of the human-world creation where we retain some agency if only in speaking.

In other words, human agency in the Anthropocene is taking on newly paradoxical aspects: on the one hand, the human species has achieved the (scaled-up) status of a geological force that has strewn industrial particulates across the entire surface of the planet as according to recent stratigraphic debates (Crutzen and Stoermer; and Chakrabarty); on the other, our individual choices for change diminish down proportionately in contrast to the vastness of our species-wide planetary impact. This development radically shifts the meaning of human activity in terms of individual subjectivity and agency and the relationship to the non-human (Dürbeck, et al.). Further exacerbating the disturbing paradoxes of our disparate levels of agency, some groups of human beings and some regions or nations have a much more profound (damaging) impact than others in terms of rapid alterations to the land and soil, water, and air. Thinking thus, the Anthropocene raises the question: are we (still) "subjects" individually choosing our paths, or are we part of a "mindless," geological-scale force? The many versions of human agency, whether of individuals or groups, heroic moments, cultural accomplishments, national, ethnic, and religious differences, and even our coveted freedoms might fade away in the face of this undirected geological force vast beyond our local ken. What stories can contain these contrasts?

Existing power structures beholden to fossil fiels, the resulting petronarratives, ${ }^{2}$ and the convergence of "natural history" and "human history" described by environmental historian Dipesh Chakrabarty are just several of the complications hindering understanding of the geological scale as well as the possibility of substantive political action and stories thereof (201). Never before have we been able to do and change so much on the planet technologically, and yet never have we faced such disparate scales 
of human power and powerlessness simultaneously. What does "nature" mean conceptually under these conditions of anthropogenic re-shaping of much of our planet's flows, cycles, and surface structures, and what is the human relationship to our environment that we alter, as all living beings do, yet now on a worldwide, geologically measurable level? In the Anthropocene's scale, the narrowed focus of the pastoral on rural locales may seem limited and even farcical, although ecocriticism and environments repeatedly return to a need for closeness to the local in order to make sense of, and care for, our world around us. Hence I borrow from the pastoral its local attention but darken it and ironize its bright dreams with the stain of our complicit actions in the sixth mass extinction event on planet Earth now being documented by science (Kolbert), this one brought about by human actions. Theoretically, I derive the darkness, the polluted, petroleum-fieeled "dark pastoral" from Timothy Morton's concept of "dark ecology," which rejects the idea of nature as a separate space or category and which writes human beings into what he terms the "mesh" with an ironic awareness of the connections that bind and link us:

I explore the possibility of a new ecological aesthetics: dark ecology. Dark ecology puts hesitation, uncercainty, irony, and thoughtulness back into ecological thinking... There is no metaposition from which we can make ecological pronouncements. Ironically, this applies in particular to the sunny, affirmative rhetoric of environmental ideology. A more honest ecological art would linger in the shadowy world of irony and difference. $(16-17)$

We thus approach our literary questions in the Anthropocene with dark irony and shadows paradoxically combined with the sunny pastoral's optimistic portrayal of the human potential for deeper understanding of the physical world around us. The dark pastoral contains these shadows but also the deep love for land and sea (even when dripping with oil).

In navigating the Anthropocene's often convoluted and contradictory views of the human-environment relationships, it is valuable to study both recent works of literature that have been classified specifically as "cli fi," or climate (change) fiction (Trexler), as well as older works. The pastoral trope, in particular, has a long history of portraying human beings in terms of green spaces, seasonal changes, and their engagements with the non-human (certainly sheep but more beyond that). In fact, the pastoral has its roots in the Ancient Greek texts, especially in the Idylls of Theocritus (c.316-260 B.C.), as the British ecocritic Terry Gifford notes in
Pastoral; this long history (long for human culture but not geologically) provides us with many detailed and concrete portrayals of specific species and regional areas. Furthermore, it evokes a sense of time in its typical longing for an idealized vision of the past. Gifford defines three kinds of pastoral, all with relevance for ecocriticism's environmental perspectives: first, the original literary form found in poetry and drama beginning in antiquity that already express a longing for a lost era of harmony with nature; second, the general textual references in any genre and era to rural landscapes and the countryside such as Goethe's Werther; and third, the derogatory use of the term to describe an overly idealized vision of such places that overlooks their material and economic practicalities (Gifford 1-12, 2010). Pastoral poetry of the first and second category can provide a kind of natural history report or offer celebratory songs of blissful forests and fields, as we see in the first stanza of Georg Neumark's seventeenth-century poem, "Song of Praise for the Field and Forest Life" "Loblied des Feld- und Waldlebens"): "Well is he, who lives in forests, / In our honorable shepherd's joy, / He floats always in bliss, No suffering ever aware. Undying and ever free / The shepherds and poetry." "Wohl dem, der in den Wäldern lebet, / In unserer edlen Schäferlust, / Derselbe stets in Freuden schwebet, / Kein Jammer ist ihm je bewusst. / Unsterblich ist und bleibet frei / Die Schäfer und Poeterei." [Translation mine]) The poem continues with celebration of peacefil and simple country life surrounded by trees and flowers (that are all free from the strife of the nobles and the corruption of the city). Hence the traditional forms of pastoral draw their energy from a contrast to the absent yet implied urban or power centers of human culture. They can attain their most poetic aspects precisely by overlooking, ignoring, and deceptively painting over human power struggles for land, control over species, economic practices, and exploitation of others. They look away and backward toward times of yore, a lost idyll, the golden age of peace, and the garden from which we were ejected, thereby evoking powerful nostalgia, dangerous in its potential for mapping out a contemporary world that seems separate from the land itself to which only simple people in the fields or in the past appear connected. Additionally, the traditional pastorals often conceal the realities and inequalities of the very power structures that support their idealized landscapes and seemingly peaceful settings. The pastoral usually ignores the colonial exploitation and genocide of people and places both small-scale and globally, focusing instead on a local nostalgia for a lost golden era. As Ken Hiltner writes in 
What else is Pastoral of the Renaissance pastoral imagining of distant green places, "such literature not only encouraged appreciation of environments imagined as pristine, but also the mass exploitation of these newly emerging environs. Consequently, these colonized countrysides appeared not as valuable and worth saving, but as ripe for exploitation" (Hiltner, 14). Ironically, the dark pastoral brings the hidden to light.

Reading with the dark pastoral trope means highlighting these tensions as they appear in familiar texts such as Goethe's 1774 The Sorrows of Young Werther (Die Leiden des jungen Werther), the epistolary novel in which Werther bemoans his inability to be with his beloved Lotte and his tragically changing relationship to nature. At first, he revels in the bucolic potential of nature's motherly embrace when lying prone by the stream, a moment of immersion that links him to the divine heavens and produces a pastoral-like delight (Sullivan, "Nature"). The aesthetic and yet bodily connections that he describes in this early letter in the novel from May 10 are rife with an ecological sense of relatedness and the human being's active participation in "nature": he believes that he becomes one with life in the "lovely valley" teeming with "mist" and quiet shade though a "few rays" of sun strike "the impenetrable foliage of my trees" as he lies "in the tall grass by the trickling stream and notice[s] a thousand familiar things," especially the "humming of the little world among the stalks" (Goethe, Sorropps 6). ("Wenn das liebe Thal um mich dampft, und die hohe Sonne an der Oberfläche der undurchdringlichen Finsterniß meines Waldes ruht, und nur einzelne Strahlen sich in das innere Heiligthum stehlen, und ich dann im hohen Grase am fallenden Bache liege, und näher an der Erde tausend mannigfaltige Gräsgen mir merkwürdig werden. Wenn ich das Wimmeln der kleinen Welt zwischen Halmen, die unzähligen, unergründlichen Gestalten, all der Würmgen, der Mückgen, näher an meinem Herzen fiihle...." [Leiden 15]). With typically pastoral scenes, Werther revels in company of the simple folk and their children, especially the pretty girls at the spring, later returning to his quiet retreat in order to eat his green peas. The pastoral setting upholds his sense of individual subjectivity and the agency to choose his own way. He achieves great art, at least in his mind: "I am so happy, my dear friend, so absorbed in the exquisite sense of tranquil existence, that I neglect my art. I could not draw at all now, not a single line, and yet I feel that I was never a greater painter than in such moments as these" (Goethe, Sorrows 6). ("Ich bin so glücklich, mein Bester, so ganz in dem Gefiihle von ruhigem Daseyn versunken, daß meine Kunst darunter leidet. Ich könnte jetzt nicht zeichnen, nicht einen Strich, und bin nie ein größerer Mahler gewesen als in diesen
Augenblicken" [Leiden, 15]). Werther's pastoral joy transforms into despair later in the novel for numerous reasons, several of which are most relevant for thinking the Anthropocene and its implications for human agency. For one, he remains an outsider: he cannot be one of the peasant farmers he celebrates nor a successfil bourgeois husband to Lotte (who marries Albert as per her mother's deathbed wish), and he also fails in his work at the royal court and is mocked for remaining at a party for the aristocracy. In each case, he feels unable to determine his way. Werther's failed quest to determine a social place of his own preference is mirrored by his responses to nature that begin with self-satisfied creativity responding to his retreat by the valley stream. As he moves toward despair, he also sees himself powerless in the face of nature that now appears as unbounded and destructive forces including floods, storms, and death: "Can we say of anything that it is! when all passes away-our transitory existence, hurried along by the torrent, is swallowed up by the waves or dashed against the rocks?" (Goethe, Sorropss 37). ("Kannst du sagen: Das ist! da alles vorïbergeht, da alles mit der Wetterschnelle vorüber rollt, so selten die ganze Kraft seines Daseins ausdauert, ach in den Strom fortgerissen, untergetaucht und an Felsen zerschmettert wird" [Leiden 108]). Werther's sense of agency changes from feeling connected to the small and so the divine, and self-determining (albeit abstractly with his imagined paintings), to feeling powerless except in death. He thereby acts out a kind of advanced warning of the Anthropocenc marked by a desperate sense of erased agency on a large scale both culturally and naturally. This erasure occurs, ironically, at the very historical juncture when human agency industrially begins to attain an unprecedented power and individual possibility for selfdetermination also increases, in theory, with the expanding middle class.

Werther acts as a textual bellwether for the paradoxical agentic possibilities of the individual human being during the emergence of mass industrialization and global capitalism alongside the increasing political and economic clout of the middle class, as Goethe often documents in his texts. Goethe's Werther is a tragic text famously denoting the emergence of modern subjectivity during the Late Enlightenment and European Romanticism, but, as we see when reading in light of the Anthropocene, this development occurs in conjunction with a distorted sense of both individual agency in a changing class structure and a feeling that one has lost the connection to the local, small-scale natural world. Goethe's Werther retains a rural/court delineation yet nevertheless embodies a kind of dark pastoral by acting out possible responses to the economic and 
social changes of impending modern capitalism and its individualistic consciousness confused about our power in the human-nature relationships.

The traditional pastoral portrays illusory ideals associating agriculture with a harmonious life of so-called natural beings-farmers-a trope that continues strongly today in contemporary advertising for industrialized farming. It separates middle class and wealthy individuals from such a life as a distant task done by seemingly "simple" people. This idea severs the connection to the natural world for anyone not living on a farm or in other rural settings. The landed aristocracy lives in such settings but with powerful control over the organization of the land. Yet the pastoral also has the potential to function as a contemporaneous "alternative" both to life on the estate, and more recently, to the "modern" technological or urban life, according to many ecocritics, including Gifford. It is thus hardly surprising that one of the founders of ecocriticism, Harvard's Lawrence Buell, begins his groundbreaking 1995 work, The Environmental Imagination, by stating: "I start with the subject of pastoral, for 'pastoral' has become almost synonymous with the idea of (re)turn to a less urbanized, more 'natural' state of existence. Indeed, this entire book, in focusing on art's capacity to image and remythify the natural environment, is itself a kind of pastoral project" (31). Buell's assertion thus confirms the continued relevance of the pastoral but with an emphasis on looking backward; this trajectory is what I propose to change with the "dark" pastoral trope that instead looks at what we have now and formard to the fiture. The darker pastoral replaces its antecedents' deep nostalgia with awareness of our inevitable immersion in natural cycles as well as an understanding of the industrial impact of humanity's large-scale actions on the entire biosphere of the Earth. Furthermore, it rewrites the land to include the soil under our feet whether in cities or elsewhere; this inclusive view is where the dark pastoral differentiates itself from Gifford's "post-pastoral."

Yet we do not want to dismiss even the traditional pastoral since it very often offers both deception and a productive double move toward exposure and contradiction. According to Gifford and Buell, the pastoral contains contradictory impulses, and unresolved tensions between the "natural" and altered land are inherent to the pastoral broadly. This fact leads Gifford to highlight the pastoral's ample "postmodern" potential despite its ancient heritage (Gifford 2014, 19). Indeed, the so-called nature of the pastoral is actually an idealization of rural landscapes altered by human agricultural practices and occupied by sheep and other animals cultivated by human culture so that it is, in fact, a site of domesticated animals and/or a "garden" of sorts created for our needs. The pastoral, in other words, simultaneously depicts and elides the human shaping of the landscape and is thus an apt genre for this project studying the Anthropocene's paradoxes. It seems the more that we alter the landscapes (and seascapes and climate), the more we relish images of seemingly eternal, pristine nature.

Idealized images of nature in the old-fashioned sense of the term tend to split into either peaceful pastoral lands or the wild and sublime-like beauty of the non-human. Mixes of the two, as in Werther, tend to bring chaos. Disasters disrupt the pastoral and feed into the fierceness of the wilds; in the Anthropocene, however, there is a collapsing of terms such as nature-culture and natural-cultural catastrophes (flooding and landslides due to deforestation, extreme wildfires due to forest management, allowing brush to accumulate, drought from overfarming, or stronger storms and rising waters with climate change, just to mention a few of many examples). Goethe's study of rivers and mines feeds his later texts with a complexity of understanding the human role in diverting water and the ensuing problems, particularly since the massive re-shaping of rivers was underway during Goethe's lifetime in Europe and especially Germany (Blackbourn). Other texts of the early Anthropocene also provide insightful mixes of nature-culture catastrophes such as Heinrich von Kleist's 1807 novella The Earthquake in Chili (Das Erdbeben von Chili). As Christoph Weber demonstrates in From God's Justice to Fateful Nature: The Representation and Coperage of Natural Catastrophes in the 18th Century (Vom Gottesgericht zur verbängnisvollen Natur: Darstellung und Bewältigung von Naturkatastrophen im 18. Jabrbund ert), the discourse of earthquakes has long debated the human role in earthquakes, including ancient discussions of immorality and God's wrath as the cause (which continue in reference to many disasters in the USA currently) as well as scientifically founded analyses of human intervention in the land. ${ }^{3}$ In this sense, the Anthropocene discourse about human-induced "natural" disasters builds on long-term discussions about causes, whether theological, moral, practical, or scientific.

Kleist's novella centers precisely on the themes of causation and the contrast of natural and human violence. The initial earthquake at the tale's beginning prevents the tragic death of two young lovers, Josephe and Jeromino. The still unwed Josephe had, shockingly, given birth on the steps of a convent to her love-child with Jeronimo and is thus being held at the convent awaiting her execution; because of the earthquake, she 
escapes through the rubble along with her baby. Jeronimo is just about to commit suicide in his prison cell in despair at the thought of her upcoming execution when he, too, is saved by the destruction that cracks open the prison walls and thus frees him. They both manage to navigate through the devastation and scenes of horrific death, rather coincidentally fleeing to the same lovely forest and field where they find each other again. Briefly reunited because of the earthquake's horror, they rejoice in an Eden-like garden of beauty, assuming that their survival of the quake indicates absolution from guilt. The little family celebrates with tears of joy and pastoral beauty resplendent with almost ironic poetic touches:

In the meantime the loveliest of nights had fallen, wonderfully mild and fragrant, silvery and still, a night such as only a poet might dream of. Everywhere along the banks of the stream, in the glittering moonlight, people had settled and were preparing soft beds of moss and foliage on which to rest after so harrowing a day.... Jeronimo and Josephe slipped away into a denser part of the wood, not wanting to give offence to anyone by the secret exultation of their own hearts. They found a splendid pomegranate tree, its outspread branches heavy with scented fruit, and high on its crest the nightingale piped its voluptuous song. (Kleist, Earthquake 35)

(Indessen war die schönste Nacht herabgestiegen, voll wundermilden Duftes, so silberglänzend und still, wie nur ein Dichter davon träumen mag. Überall, längs der Talquelle, hatten sich, im Schimmer des Mondscheins, Menschen ijiedergelassen, und bereiteten sich sanfte Lager von Moos und Laub, um von einem so qualvollen Tage auszuruhen. ... Jeronimo und Josephe [schlichen] in ein dichteres Gebüsch, um durch das heimliche Gejauch $z$ ihrer Seelen niemand $z u$ betrüben. Sie fanden einen prachtvollen Granatapfelbaum, der seine $\mathbf{Z}$ wcige, voll duftender Frïchte, weit ausbreitete; und die Nachrigall flötete im Wipfel ihr wollüstiges Lied. (Erdbeben 692))

In this lovely garden scene of equality, all survivors join together and help each other so that the harsh moral landscape is briefly broken and interrupted by the natural disaster. This moment of catastrophe-induced peace is short lived, however, in that, they return the next day to the city church along with its notions of divine justice. In the final scene in, and in front of the church, the two young lovers are brutally sacrificed, murdered, as scapegoats blamed for what is interpreted to be the divine punishment bringing the earthquake's devastation (Weber). Keist's dramatically brief pastoral is thus even more dramatically undermined; this three-step process of impending (social) demise, earthquake disaster (ironically) bringing pastoral harmony and saving the young lovers, and their final bloody deaths denoting sex as the cause of earthquakes derives its power precisely from the alluring harmony of the all-too-brief pastoral beauty that ends so abruptly when the survivors return to church and are blamed for the damage. Debates about causes and blame still dominate in the discussion of climate change, often overshadowing any efforts at actual social change and covering up the complexity of natural-cultural catastrophes.

Disaster discourse is also central to many analyses of the Anthropocene. The impact of catastrophes is often amped up through the disruption of pastoral-like settings, even if only offered as a glimpse of the otherness of the rural. In various literary tales from the Anthropocene that explore the land, the pastoral appears briefly and sometimes negatively but mostly to be overwritten and destroyed by such changes as new class constructs, modern extractive practices, and changing technologies leaving in their wake the razed forests in Annette von Droste-Hülshoff's 1842 The Jew's Beech (Die Judenbuche), the stinking, poisoned creek water from the sugar factory in Wilhelm Raabe's 1884 Pfister's Mill (Pfisters Miible), and the radioactive gardens in Christa Wolf's 1987 novel Accident (Störfall) documenting the Chernobyl disaster that spread radiation across Europe and rendering her carefilly tended plants inedible. ${ }^{4}$ In contrast, Theodor Storm's 1888 novella, The Dyke Master (Der Schimmelreiter), presents the pastoral as the problem iwelf rather than the lost ideal. In this partially "technophilic" text celebrating the possibilities of applying rational science and modern technology in order to counter the power of waves, the old ways of farming and fishing are brutally limiting to Hauke Haien and his modern mathematical thinking. Storm's village by the sea is not portrayed as idyllic, but it is nevertheless a rural community existing in long-term continuity of sorts with nature, thus qualifying it as "pastoral" in Gifford's second category. Though, in this case, it is the land in eternal battle against the onslaught of the sea. Innovation of the dike is both improvement and disruption for the rural community. The focus on altered traditions is standard in the pastoral, and technophilic answers are standard to the Anthropocene. Hence we read Storm's novella in terms of the dark pastoral and the changing forms of human-land/sea relations, whether for the better or the worse. As Kate Rigby notes in her ecocritical analysis of the Dyke Master: "From an ecological materialist perspective, it is here, 
in the illusion of individual self-determination, puritanical self-denial, and the domination of 'nature', that Hauke's deeper fault lies, and from which the tragedy unfolds: one that is neither a divine judgment nor a natural disaster, but a natural-cultural calamity, in which diverse human and nonhuman actors and factors are unhappily entangled" (128). Storm's novella problematizes the very notion of pastoral peace, suggesting it is instead a dark and superstitious realm needing revision with modern innovation, yet he also, as Rigby writes, portrays the goal of dominating nature as an equally troubled gesture lacking in understanding of his local culture and human ecology's entanglement that cannot simply be unwoven with clear thinking and, in Val Plumwood's term, "technofixes." Indeed, for all of its celebration of the dike still standing hundreds of years after Hauke Haien's death, the novella is strangely non-rational: it is, in essence, a ghost story playing with the question of his death, his mysteriously spooky white horse, and local superstitions about how to treat the land.

Hauke's successfill calculations are not readily accepted by the rural people of Frisia though he still manages to create a new dike that can withstand much greater power of storms due to its long, gradual slope. This accomplishment comes with a high cost, according to Storm's tale: Hauke, like a new capitalist, engages in unceasing self-sacrifice and personal labor to the extent that he has no time for his wife, not even in terms of intimacy so that they long remain childless. When they do finally have a daughter, she is handicapped, a fact which the superstitious village folk interpret as divine punishment for messing with traditions and lacking proper religious sentiments. When the inevitable 100-year storm occurs, the new dike holds but the water breaks through at the point where the old construction connects to the new. The initial failure of the dike at the link between systems can finction as a metaphor for the crises of the Anthropocene caught between long-term views of the world and disturbing new ones.

Hauke Haien's construction is hindered by village superstitions, but it lasts well beyond his own demise into the text's future, as we see in the narrator's framing tale that takes place much later. The narrator describes traveling along the now long-standing dike on the stormy northern coastline of Schleswig-Holstein. While riding past a village, a storm and a ghostly figure rushing by force him to take shelter in an inn. There he hears the story of the long-dead dike master, Hauke, who battled against the sea and against local traditions, only to become that ghost. Ultimately, his years of work and precise mathematical models produce a very durable and modern dike but also long-lasting social conflicts that have no resolution. The tale ends ambiguously in that the "rational" Hauke finally fulfills the local belief that something "living" must be sacrificed, tossed into the dike as part of its material, in order for it to last: as he rushes toward his family lost to the waves of the 100-year storm, he purposely joins them in death, in sacrifice, by plunging with his white horse into the floodwaters. Though he earlier prevented a small dog from being sacrificed in this fashion, he now enacts the very deed he sought to overcome. This contrast of scientific calculations and superstitions sets up a tension for the entire novella, one that is not resolved since the story itself is, very straightforwardly, a ghost tale that emerges with the dike as technological wonder. In fact, this tension is paradigmatic for the Anthropocene as an era that maintains paradoxical relationships to science as, on the one hand, the greatest tool that can solve any challenges we face and yet, on the other hand, problematic information that can simply be rejected when it conflicts with one's ideology. Storm maps out much of the terrain of current political, economic, and ecological debates in this little novella from 1888 with its ambiguous end: both the dike and the ghost live on with no clear reconciliation. The Anthropocene's paradoxes are many.

The traditional pastoral offers frames that encompass the vast in the small: local villages and fields are set against large-scale storms or dis the nameless political powers that leave "Michael," in William Wordsworth's famously named pastoral poem, for example; bereft of his land and bemoaning the loss of his son to the allure of the city. Yet the pastoral's inherent critique of urban or courtly politics and power, whether merely implied or openly stated as with Wordsworth and Goethe, gains urgency in the age of the Anthropocene when we can no longer find places on Earth free of human impact. Where then is the longed-for space of "freedom" or harmony so artificially idealized in the pastoral (itself usually a setting of human manipulation)? Such sites seem short lived, as we saw in Kleist, but also in more recent German literary texts where they are quiclely disrupted with dramatic disasters in a manner very similar to one of the first environmentally activist texts, Rachel Carson's 1962 Silent Spring, which also begins with a pastoral setting of beautifil rural areas only to highlight the silence brought about by the massive die off of birds due to pesticides. An analogous example in the German tradition is Gudrun Pausewang's 1987. young adult novel The Cloud (Die Wolke) describing a fictional nuclear explosion, a "Supergau," which begins with a beautiful description of spring's arrival: 
A strong breeze blew on this Friday morning. When Janna-Berta gazed out of the window, she saw the young birch leaves glitter in the sun. The shadows of the branches trembled on the asphalt of the schoolyard. Over the pavilion's roof, it snowed cherry blossoms. The sky was deep blue. Only individual clouds, white and light as if made of cotton, flowed by above. For a May morning, it was unusually warm. The view was clear. Suddenly, the siren screamed. (Pausewang, my translation)

(An diesem Freitagmorgen wehte eine starke Brise. Wenn Janna-Berta aus dem Fenster schaute, sah sie die jungen Birkenblätter in der Sonne glitzern. Die Schatten der Zweige zitterten auf dem Asphalt des Schulhofs. Ưber die Pavillondächer schneite es Kirschenblätter. Der Himmel war tiefblau. Nur vereinzelte Wolken, weiß und leicht wie aus Watte, trieben über ihn hin. Für einen Maimorgen war es außergewöhnlich warm. Die Sicht war klar. Plötzliche heulte die Sirene. (Pausewang 13)).

The beautiful sunny morning, warm and awash with cherry blossoms and puffy white clouds, is radically altered with the siren alerting the school to a disaster. Soon, all learn that a nuclear explosion has occurred and the children are sent home to find their own way through the chaos. Immediate institutional relinquishment of responsibility occurs. From a single glimpse of pastoral beauty to cultural breakdown is just one step in the novel. And there is no escape from the fallout; Pausewang loads The Cloud with horrifying and lengthy descriptions of children suffering unspeakable deaths from radiation poisoning after they have fled across fields of grass and through small villages. The government fails to act. The pastoral has gone radioactive.

Thinking with the dark pastoral trope means balancing these extreme contrasts of the Anthropocene and exploring their paradoxes with irony, much in the way that Morton describes the irony of "dark ecology" that posits awareness of our ecological dependency, finally, at the same moment that we realize the full scope of how we have been re-shaping and thus damaging the planet's ecological systems. The irony, however, extends further: by giving up the metaposition that claims objective distance, we realize that we are in the thick of things as a species causing broad-scale change at the very moment that we also realize that we are in the "dark" when it comes to controlling this global impact. From within ecology and ongoing pastoral views, we tap into, and darken, the pastoral's potential for re-envisioning the human-land entanglements and seek to expose and undermine lingering delusions of the cornucopian economic beliefs that include no recognition of the environmental costs of our industrial activities. ${ }^{6}$ That is, the dark pastoral mirrors the standard views in the Anthropocene that purposefilly conceal underlying power structures and that navigate agency in convoluted ways. This concealment is parallel to capitalist economic practices that calculate costs and profits without any (or minimal) reference to environmental damage, pollution, or long-term impact of depleted soil, deforestation, mountain-top mining that destroys the water systems of entire areas, climate change, and so on. Hence the pastoral provides a fine groundwork for becoming aware of these blind spots since it potentially both enacts and simultaneously critiques the neglect of what the environmental philosopher Val Plumwood describes as our own "enabling conditions": "the body, ecology and non-human nature" (17). Human agency often asserts itself through the denial of the relevance of these very conditions: we are "rational" "subjects" who ranscend! Yet with the dark pastoral's exploration of human-environment and human-land relationships, in contrast, we seek models of agency able to acknowledge that we are in the mesh, reliant upon the body, ecology, and the non-human while still being able to think and act individually and culturally. Tracking our historical and cultural developments as ecological should not mean capitulating all agency, even if these literary examples seem to do so. Storytelling, though, is an active voice.

In addressing the Anthropocene through the dark pastoral, there are many voices beset by nostalgic longing for lost nature and our powerlessness to counter it. In Ilija Trojanow's 2011 climate change novel, The Lamentations of Zeno (EisTau), for example, the tragic gaze looking backwards is the glaciologist Zeno Hintermeier's desire for a melted glacier, his beloved object of study. ${ }^{7}$ There is a sense of lost agency particularly with the increased scientific knowledge. The novel opens after the glacier has already melted, and Zeno has already succumbed to despair and so abandoned his home in the European Alps and his academic career as a glaciologist. $\mathrm{He}$ is at sea, both metaphorically and literally, chasing ice as the resident expert on a cruise ship of rich tourists experiencing the Antarctic: This Cassandra-like job of trying to educate his guests on the beauties of ice and the relevance of iw melting for all of our lives leads to as much agony as the original loss of his glacier. He finally-both before the novel begins and at the end since this is a multi-layered, non-linear tale-leaves all the tourists on the ice to perform an artistic response to climate change in the shape of a massive SOS formed by human bodies 
lining up on the ice. While they enact this artistic, and then real, plea for help, Zeno dashes off with the cruise ship, a modern pirate with a foolish mission to evade humanity by sailing out to sea. He finally takes a rather Faustian-Homunculus dive into the waters. "I will go out, when it is dark, I will fly, surrounded by white blood fish and sea squirts that float below me, from stingrays that will glide away above me, I will fly until my blood turns to ice." ("Ich werde hinausgehen, wenn es dunkelt, ich werde fliegen, umgeben von Weißblutfischen und Seescheiden, die unter mir schweben, von Rochen, die über mich hinweggleiten, ich werde fliegen, bis mein Blut zu Eis geronnen ist"; Trojanow, 167, translation mine). Zeno thereby achieves a kind of oneness with the water of lost glaciers and turns himself into ice with a Wertherian suicidal act, an absurdity that prevents readers from easy sympathy. Overwhelmed with nostalgia, Zeno appears more of an inefficient fool of sorts than an inspiring character. His desperate choices enact a significant aspect of the dark pastoral as a trope for the Anthropocene: like Zeno, we are already deep within the processes of change, and when we are lost in nostalgia for lost glaciers (etc.) as objects of desire, we can be distracted from becoming aware of possible actions (not including absconding with cruise ships and diving into frozen waters). Worrisome, too, are the many unheard voices demanding climate action. In that, Zeno is not alone.

In sum, Trojanow portrays Zeno as a flawed and unsympathetic character whose actions and travels map out an apparent paradox of the Anthropocene regarding human agency, which is that our options for action may seem to be only the Promethean power to manipulate the world at will or Zeno's and Werther's desperate acts of suicide that focus only on the demise of the individual body. It is either full, god-like technological agency over the world or total capitulation of all possibility of action other than bodily self-destruction. Instead, the Anthropocene should be more like Trojanow's novel itself: a lesson in our ecological immersion, our widespread species' impact, and yet also in the possibility of all kinds of other smaller kinds of actions-and narratives-both political and economic. The view from the dark pastoral as a description of our state in the Anthropocene extends toward the vastness of the geological yet also looks closely at the local; it deploys our human agency with irony but not without all power. In the dark pastoral, we see the bright colors of nature without pretending that they, and we, are immune to the impact of fossil firels flowing along the land both rural and urban and into rivers, oceans, our water, and our food.

\section{Notes}

1. The project of re-thinking the pastoral in the Anthropocene is widespread, and the dark pastoral is but one of the several recent projects in ecocriticism, including Terry Gifford's "post-pastoral," Greg Garrard's "radical pastoral," David Farrier's "toxic pastoral," and the emphasis on lyric forms in the "necropastoral." Joeylle McSweeney defines this latter trope as follows: "The Necropastoral is a political-aesthetic zone in which the fact of mankind's depredations cannot be separated from an experience of "nature" which is poisoned, mutated, aberrant, spectacular, fill of ill effects and affects..."

2. For a discussion of "petro-texts" in the Anthropocene, see Sullivan, 2017: There are numerous recent discussions of oil culture. See especially Barrett and Worden; and LeMenager.

3. Recent studies of fracking have found significant correlation to increased earthquakes; see Hildenbrand, et al., and Weingarten, et al.

4. For ecocritical readings of von Droste-Hïlshoff, see Gray; of Raabe, see Wilke; and of Wolf, see Heise, esp. pp. 199-200.

5. Plumwood addresses the naïve hopes for technofixes to all environmental problems, pp. 6-8.

6. See Garrard's definition in Ecocriticism, 2012, of "cornucopian" views based on the belief that there are no ecological limits, only limits to our imagination.

7. See Axel Goodbody's chapter in this volume on climate change fiction, especially Trojanow.

\section{WORKS CITEd}

Barrett, Ross, and Daniel Worden, eds. Oil Culture. U of Minnesota P, 2014.

Blackbourn, David. The Conquest of Nature: Water, Landscape, and the Making of Modern Germany. Norton, 2007.

Buell, Lawrence. The Environmental Imagination: Thoreau, Nature Writing, and the Formation of American Culture. Belknap of Harvard UP, 1995.

Carson, Rachel. Silent Spring. Houghton Mifflin, 1962.

Chakrabarty, Dipesh. "The Climate of History: Four Theses," Critical Inquiry, vol. 35, 2009, pp. 197-222.

Crutzen, Paul J., and Eugene F. Stoermer. "The "Anthropocene." Global Change Nerosletter, vol. 41, 2000, pp. 17-18. 
DeLoughrey, Elizabeth, and George B. Handley, eds. Postcolonial Ecologies: Literatures of the Environment. Oxford UP, 2011.

Droste Hülshoff; Annette von. Die Judenbuche. Sümtliche Werke: Prosa, edited by Bodo Plachta and Winfried Woesler, Wissenschaftliche Buchgesellschaft, 1998, pp. 11-62.

Dürbeck, Gabriele, Caroline Schaumann, and Heather I. Sullivan, "Human and Non-Human Agencies: The Anthropocene, Material Ecocriticism, and the Contributions of Literature." Ecozon@, vol. 6, no. 1, 2015, pp. 118-36.

Farrier, David. "Toxic Pastoral: Comic Failure and Ironic Nostalgia in Contemporary British Environmental Theatre." Journal of Ecocriticism, vol. 6 , no. 2, 2014, pp. 1-15;

Garrard, Greg. Ecocriticism. Routledge, 2012.

. "Radical Pastoral?" Studies in Romanticism, vol. 35, no. 3, 1996, pp. 449-465.

Gifford, Terry. Pastoral. Routledge, 2010.

-. "Pastoral, Ant-Pastoral, and Post-Pastoral." The Cambridge Companion to Literature and the Environment, edited by Louise Westling, Cambridge UP, 2014, pp. 17-30.

Goethe, Johann Wolfgang. Die Leiden des jungen Werthers. Edited by Waltraud Wiethölter, Klassiker, 2006

. The Sorrows of Young Werther. Translated by Victor Lange, Suhrkamp, 1988.

Gray, Richard T. "Red Herrings and Blue Smocks: Ecological Destruction, Commercialism, and Anti-Semitism in Annette von Droste-Hiilshoff's Die Judenbuche."German Studies Review, vol. 26, no. 3, 2003, pp. 515-542.

Heise, Ursula K. Sense of Place and Sense of Planet. Oxford UP, 2008.

Hildenbrand, Zacariah Louis, Doug D. Carlton, et al. "A Comprehensive Analysis of Groundwater Quality in the Barnett Shale Region." Environmental Science and Technology, 17 June 2015. 1-27.

Hilter, Ken. What Else is Pastoral?: Renaissance Literature and the Environment. Cornell UP, 2011.

Huggan, Graham, andHelen Tiffin. Postcolonial Ecocriticism: Literature, Animals, Environment. Routledge, 2010.

Iovino, Serenella, and Serpil Oppermann, eds. Material Ecocriticism. U of Virginia P, 2014 .

Kleist, Heinrich von. Das Erdbeben in Chili. Heinrich pon ICleist: Werke in einem Band, edited by Helmut Sembdner, Carl Hanser, 1990, pp. 687-99.

. The Earthquake in Chile. The Marquise of $O-A$ And Other Stories. Translated by David Luke and Nigel Reeves, Penguin, 1978, pp. 31-4l.

Kolbert, Elizabeth. The Sixth Extinction: An Unnatural History. Henry Holt, 2014 .
Latham, Rob. "Biotic Invasions: Ecological Imperialism in New Wave Science Fiction." The Yearbook of English Studies, vol. 37, no. 2, 2007, pp. 103-19.

LeMenager, Stephanie. Living Oil: Petroleum Culture in the American Century. Oxford UP, 2014.

McSweeney, Joeyelle. "The Necropastoral is a political-aesthetic zone in which the fact of mankind's depredations cannot be separated from an experience of "nature" which is poisoned, mutated, aberrant, spectacular, full of ill effects and affecw...." http://www.poetryfoundation.org/harriet/2014/04/whatis-the-necropastoral/; accessed 15 July, 2014.

Morton, Timothy. The Ecological Thought. Harvard UP, 2010.

Neumark, Georg. Fortgepflantzter musikalisch-poetischer Lustwald. Georg Sengenwald, 1657. Google Books, accessed 15 Feb, 2016.

Nixon, Rob. Slow Violence and the Environmentalism of the Poor. Harvard UP, 2011.

Pausewang, Gudrun. Die Wolke. Ravensburger Buchverlag 1989.

Rigby Kate. "Of Mice and Men and Aquatic Flows: Distributed Agency in Theodor Storm's Der Schimmelreiter." New German Critique, vol. 128, 2016, pp. 153-76.

Plumwood, Val. Environmental Culture: The Ecological CrisisofReason. Routledge, 2001.

Raabe, Wilhelm. "Pfisters Mühle." Sämtliche Werke, vol. 16. Vandenhoeck and Ruprecht, 1970.

Roos, Bonnie, and Alex Hunt, eds. Postcolonial Green: Environmental Politics and World Narratipes. U of Virginia P, 2010.

Shiva, Vandana. Soil not Oil. South End Press, 2008.

Storm, Theodor. "Der Schimmelreiter." Der Schimmelreiter und andere Nopellen, edited by Hartmut Vinçon, Goldmann, 1979, pp. 164-274.

. The Dyke Master. Translated by Denis Jackson, Angel Books, 1996.

Sullivan, Heather I. "Material Ecocriticism and the Petro-Text." The Routledge Companion to the Environmental Humanities, edited by Ursula $K$ Heise, et al., Routledge, forthcoming, 2017: 414-423.

- "Nature and the 'Dark Pastoral' in Goethe's Werther." Goethe Tearbook, vol. 22, 2015, pp. 115-32

Trexler, Adam. Anthropocene Fictions: The Nopel in a Time of Climate Change. U of Virginia P, 2015.

Trojanow, Ilija. Eis Tau. Carl Hanser, 2011.

- The Lamentations of Zeno. Verso, 2016.

Weber, Christoph. Gottesgericht zur perbängnisvollen Natur: Darstellung und Bewältigung von Naturkatastrophen im 18. Jabrbundert. Felix Meiner Verlag, 2015. 
Weingarten, M., et al. "High-rate injection is associated with the increase in U.S. mid-continent seismicity." Sciencemag.org, vol. 348.624l, June 2015, pp. 1336-440.

Wilke, Sabine. "Pollution as Poetic Practice: Glimpses of Modernism in Wilheim Raabe's Pfisters Müble." Colloquia Germanica, vol. 44, no. 2, 2011 , pp. 195-214.

Wolf, Christa. Störfall: Nachrichten eines Tages. Luchterhand, 1987.

Wordsworth, William. "Michael: A Pastoral Poem." Bartleby.com: Great Books Online. 1993-2015. http://www.bartieby.com/41/372.html. 